\title{
IMPLEMENTASI UNIT PENGOLAH AIR MINUM UNTUK MENGHILANGKAN KADAR MANGAN (Mn) TINGGI Studi Kasus : Implementasi Pengolah Air Siap Minum di Pondok Pesantren Ummul Quro, Kabupaten Trenggalek
}

\author{
Imam Setiadi dan Satmoko Yudo \\ Pusat Teknologi Lingkungan, BPPT, Kawasan Puspiptek, Tangerang Selatan, 15314, Indonesia \\ Email : imam.setiadi@bppt.go.id ; satmoko.yudo@bppt.go.id
}

\begin{abstract}
ABSTRAK
Kabupaten Trenggalek, Provinsi Jawa Timur merupakan daerah yamg memiliki potensi kekayaan tambang yang tersebar di beberapa lokasi yang belum dikembangkan secara optimal. Menurut data Dinas Koperasi, Industri, Perdagangan, Pertambangan dan Energi Kabupaten Trenggalek menunjukkan bahwa daerah di Kecamatan Gandusari mempunyai potensi tambang mangan sekitar 1,03 juta ton. Desa Melis merupakan salah satu desa yang terletak di Kecamatan Gandusari, Kabupaten Trenggalek, di desa ini sumber air penduduk mengandung mangan (Mn) cukup tinggi. Mengkonsumsi air yang mengandung mangan tinggi dapat mengganggu kesehatan. Salah satu cara untuk menurunkan kadar mangan tinggi dalam air adalah melakukan pengolahan air terlebih dahulu sebelum dikonsumsi, untuk itu Pusat Teknologi Lingkungan BPPT telah membangun pilot plan teknologi pengolahan air siap minum (Arsinum) di Pondok Pesantren Ummul Quro, Desa Melis, Kecamatan Gandusari, Kabupaten Trenggalek. Proses pengolahan air siap minum ini dapat mengurangi kadar mangan dan memenuhi persyaratan kualitas air minum yang dikeluarkan oleh Kementerian Kesehatan RI Nomor 492/MENKES/PER/IV/2010.
\end{abstract}

Kata kunci : Sumber air, mangan, pengolahan air siap minum (Arsinum)

\section{DRINKING WATER TREATMENT UNITS IMPLEMENTATION TO REDUCE HIGH MANGAN (Mn) Case Study : Drinking Water Treatment Implementation at Pondok Pesantren Ummul Quro, Kabupaten Trenggalek}

Center for Environmental Technology, BPPT, Puspiptek Area, South Tangerang, 15314, Indonesia Email : imam.setiadi@bppt.go.id ; satmoko.yudo@bppt.go.id

\begin{abstract}
Trenggalek Regency, East Java Province is a region that has potential mining wealth that is spread in several locations that have not been developed optimally. According to data from the Office of Cooperatives, Industry, Trade, Mining and Energy, Trenggalek Regency shows that the area in Gandusari Subdistrict has a potential of around 1.03 million tons of manganese mine. Melis Village is one of the villages located in Gandusari Subdistrict, Trenggalek Regency, in this village the water source of the population containing manganese $(\mathrm{Mn})$ is quite high. Consuming water containing high manganese can interfere with health. One way to reduce high levels of manganese in water is to do water treatment first before consumption, for that BPPT Environmental Technology Center has built a pilot plan for readyto-drink (Arsinum) water treatment technology at Ummul Quro Islamic Boarding School, Melis Village, Gandusari District, Regency Trenggalek. The processing of ready-to-drink water can reduce manganese levels and meet drinking water quality requirements issued by the Indonesian Ministry of Health Number 492 / MENKES / PER / IV / 2010.
\end{abstract}

Keywords : source of water, manganese, processing ready-to-drink water (Arsinum) 


\section{PENDAHULUAN}

\subsection{Latar Belakang}

Air merupakan komponen yang sangat penting bagi kehidupan manusia. Setiap hari manusia rata-rata membutuhkan air sebesar 120 liter per orang (Anonimous 1, 2007), seperti untuk keperluan minum, masak, mandi cuci dan lain sebagainya. Akan tetapi pelayanan air minum masih terbatas dan tidak mampu mengimbangi laju kebutuhan penduduk yang terus meningkat setiap tahunnya.

Pengadaan air bersih di Indonesia secara nasional khususnya wilayah perdesaan masih belum mencukupi sekitar 60,72\% (Ahyar, A. 2017). Untuk daerah yang belum mendapatkan pelayanan air bersih dari PDAM umumnya mereka menggunakan air permukaan, air tanah (sumur), air sungai, air hujan atau air dari sumber lainnya.

Permasalahan yang ada saat ini adalah banyak wilayah di Indonesia yang kualitas sumber air permukaan ataupun air tanahnya tidak memenuhi syarat untuk digunakan sebagai air minum. Contohnya di desa-desa di Kecamatan Gandusari, Kabupaten Trenggalek Jawa Timur, sumber airnya diketahui mempunyai kualitas air yang mengandung kadar mangan (Mn) tinggi. Kabupaten Trenggalek merupakan wilayah yang mempunyai cadangan mangan cukup besar, hal ini didasarkan pada kondisi geologi kabupaten Trenggalek yang berada pada jalur pegunungan selatan yang dominan tersusun dari batu gamping (Yulianti, D, 2013). Terdapat 4 kecamatan yang mempunyai potensi mangan yaitu Pogalan (60 juta ton), Gandusari (25 juta ton), Watulimo (17 juta ton) dan Bendungan (10 juta ton) (Anonimous 2, 2014).

Meskipun mangan merupakan salah satu unsur esensial bagi manusia dan hewan, tetapi paparan kronis sampai pada dosis yang tinggi dapat membahayakan kesehatan dengan target adalah sistem saraf (Ashar, T. 2007).

Untuk mengatasi masalah tersebut, salah satu alternatifnya adalah dengan membangun unit pengolah air minum dengan kualitas yang memenuhi pesyaratan baku mutu kesehatan. Pusat Teknologi Lingkungan, Badan Pengkajian dan Penerapan Teknologi (PTL-BPPT) telah melakukan diseminasi teknologi pengolahan air siap minum (Arsinum) di Pondok Pesantren Ummul Quro, Kabupaten Trenggalek untuk menanggulangi permasalahan sumber air dengan kandungan mangan (Mn) tinggi.

\subsection{Tujuan}

Tujuan utama dari kegiatan ini adalah melakukan implementasi teknologi pengolahan air untuk menghilangkan kadar mangan tinggi menjadi air siap minum dengan kualitas memenuhi syarat baku mutu kesehatan.

\section{BAHAN DAN METODOLOGI}

\subsection{Lokasi dan Waktu}

Pembangunan unit pengolahan air minum dilakukan di Pesantren Tahfidzul Qur'an Ummul Quro yang berada di Desa Melis, Kecamatan Gandusari, Kabupaten Trenggalek, Jawa Timur. Sedangkan waktu pembangunan unit pengolah air siap minum dilakukan pada bulan September 2018.

\subsection{Bahan}

Bahan yang digunakan dalam kegiatan ini antara lain :

a. Bahan untuk wawancara, presentasi dan pelatihan;

b. Bahan untuk perakitan dan instalasi unit pengolah air minum;

c. Bahan kimia untuk senyawa disinfektan untuk membunuh kuman serta untuk proses oksidasi.

\subsection{Metode}

Metode yang digunakan kegiatan ini adalah sebagai berikut :

a. Survei

Metode survai dilakukan untuk mengetahui jumlah orang yang akan dilayani, pengambilan contoh air baku yang digunakan sehari-hari untuk di analisa di laboratorium dan survai calon lembaga pengelolanya. Data tersebut menjadi dasar pertimbangan penentuan lokasi, pengelola dan sistem/jenis proses serta kapasitas unit pengolahan air minum.

b. Disain Unit Pengolah Air Minum

Metode disain dilakukan untuk mendapat unit pengolah air minum yang didasarkan kepada data kualitas sumber air baku di daerah dan jumlah orang yang akan dilayani, maka semua pertimbangan di atas akan menentukan disain unit dalam proses pengolahan air.

\section{HASIL DAN PEMBAHASAN}

\subsection{Air Mengandung Kadar Mangan (Mn) Tinggi}

Mangan (Mn) dalam jumlah kecil $(<0,5$ $\mathrm{mg} / \mathrm{liter}$ ) dalam air tidak menimbulkan gangguan kesehatan, melainkan bermanfaat dalam menjaga kesehatan otak dan tulang. 
Tetapi mangan $(\mathrm{Mn})$ dalam jumlah besar $(>0,5$ $\mathrm{mg} /$ liter), neurotoksik (zat beracun pada jaringan saraf) (Febrina, L. \& Ayuna, A. 2015). Suatu studi epidemiologi yang dilakukan di Yunani menunjukkan bahwa konsumsi air minum yang secara alami mengandung konsentrasi mangan yang cukup tinggi seumur hidup, berisiko menimbulkan gejala-gejala neurologi dan peningkatan retensi mangan (Ashar, T. 2007). Efek mangan terjadi terutama di saluran pernapasan dan di otak. Gejala keracunan mangan adalah halusinasi, pelupa dan kerusakan saraf. Mangan juga dapat menyebabkan Parkinson, emboli paru-paru dan bronkitis. Ketika orang-orang yang terkena mangan untuk jangka waktu lama mereka menjadi impoten. Suatu sindrom yang disebabkan oleh mangan memiliki gejala seperti skizofrenia, kebodohan, lemah otot, sakit kepala dan insomnia (Aisyahwalsiah, A, dkk. 2010).

Konsentrasi mangan di dalam sistem air alami umumnya kurang dari $0,1 \mathrm{mg} /$ liter, jika konsentrasinya melebihi $1 \mathrm{mg} /$ liter, maka dengan pengolahan biasa sangat sulit untuk menurunkan konsentrasinya hingga mencapai pesyaratan sebagai air minum (Said, NI. 2005). Menurut Keputusan Menteri Kesehatan Republik Indonesia Nomor 492/MENKES/PER/IV/ 2010 tentang Pesyaratan Kualitas Air Minum menetapkan kadar mangan maksimum yang diperbolehkan 0,4 mg/liter (Anonimous 3, 2010).

Pesantren Tahfidzul Qur'an Ummul Quro merupakan pondok pesantren (Ponpes) yang dikelola oleh Yayasan Nurul Fiqri yang berlokasi di Desa Melis, Kecamatan Gandusari, Kabupaten Trenggalek, Jawa Timur. Ponpes ini mempunyai santri berjumlah 443 orang dan diperkirakan di tahun ajaran baru akan ada penambahan santri baru sekitar 150 santri. Sehubungan dengan banyaknya santri yang akan beraktivitas di pondok ini, maka air minum menjadi sebuah kebutuhan pokok sehari-hari yang sangat diperlukan untuk mendukung aktivitas yang dilakukan di lingkungan sekolah ini. Untuk itu perlu disediakan kebutuhan dasar pokok yaitu air minum yang layak yang sesuai standar kesehatan, yang dapat meningkatkan standar kualitas hidup di lingkungan sekolah tersebut.

Hasil analisa kualitas air sumur/ baku di pondok pesantren pada Tabel 1 menunjukkan bahwa parameter Mangan terlarut sebesar 5,77 $\mathrm{mg} / \mathrm{liter}$, kadar mangan ini melebihi persyaratan kualitas air minum menurut Keputusan Menteri Kesehatan Republik Indonesia Nomor 492/MENKES/PER/IV/2010.
Tabel 1. Hasil Analisa Kualitas Air Sumur/Baku di Ponpes Ummul Quro

\begin{tabular}{c|l|c|c|c}
\hline No & PARAMETER & SATUAN & $\begin{array}{c}\text { Baku } \\
\text { Mutu }\end{array}$ & $\begin{array}{c}\text { Hasil } \\
\text { Air } \\
\text { Baku }\end{array}$ \\
\hline 1 & pH & - & $6-9$ & 6,87 \\
\hline 2 & Kekeruhan & NTU & 5 & 1,07 \\
\hline 3 & $\begin{array}{l}\text { Jumlah zat padat } \\
\text { terlarut (TDS) }\end{array}$ & $\mathrm{mg} / \mathrm{l}$ & 500 & 222 \\
\hline 4 & Temperatur & ${ }^{\circ} \mathrm{C}$ & $\begin{array}{c}\text { Air } \\
\text { Normal }\end{array}$ & 26 \\
\hline 5 & Klorida & $\mathrm{mg} / \mathrm{l}$ & 250 & 17,30 \\
\hline 6 & $\begin{array}{l}\text { Kesadahan } \\
\text { jumlah (CaCO3) }\end{array}$ & $\mathrm{mg} / \mathrm{l}$ & 500 & 160,00 \\
\hline 7 & Nitrit & $\mathrm{mg} / \mathrm{l}$ & 3 & $<0,1$ \\
\hline 8 & Nitrat & $\mathrm{mg} / \mathrm{l}$ & 50 & 1,55 \\
\hline 9 & Amonia & $\mathrm{mg} / \mathrm{l}$ & 1,5 & 0,02 \\
\hline 10 & Sulfat & $\mathrm{mg} / \mathrm{l}$ & 250 & 1,40 \\
\hline 11 & Flourida & $\mathrm{mg} / \mathrm{l}$ & 1,5 & 1,19 \\
\hline 12 & Besi (Fe) Terlarut & $\mathrm{mg} / \mathrm{l}$ & 0,3 & $<0,02$ \\
\hline 13 & $\begin{array}{l}\text { Kadmium (Cd) } \\
\text { Terlarut }\end{array}$ & $\mathrm{mg} / \mathrm{l}$ & 0,003 & $<0,002$ \\
\hline $\mathbf{1 4}$ & Mangan (Mn) & $\mathbf{m g} / \mathrm{l}$ & $\mathbf{0 , 4}$ & $\mathbf{5 , 7 7}$ \\
\hline 15 & $\begin{array}{l}\text { Seng (Zn) } \\
\text { Terlarut }\end{array}$ & $\mathrm{mg} / \mathrm{l}$ & 3 & $<0,008$ \\
\hline 16 & $\begin{array}{l}\text { Krom (Cr) } \\
\text { Terlarut }\end{array}$ & $\mathrm{mg} / \mathrm{l}$ & 0,05 & $<0,02$ \\
\hline 17 & $\begin{array}{l}\text { Tembaga (Cu) } \\
\text { Terlarut }\end{array}$ & $\mathrm{mg} / \mathrm{l}$ & 2 & $<0,02$ \\
\hline 18 & Nikel (Ni) Terlarut & $\mathrm{mg} / \mathrm{l}$ & 0,07 & $<0,01$ \\
\hline 19 & Total Coliform & $\mathrm{mpn} / 100$ \\
$\mathrm{~mL}$ & 50 & 23 \\
\hline 20 & E Coli & 0 & - \\
\hline & & & \\
\hline
\end{tabular}

\subsection{Penghilangan Mangan (Mn)}

Pada umumnya metode yang sering digunakan untuk menghilangkan mangan dalam air adalah dengan cara oksidasi, antara lain dengan proses aerasi-filtrasi, proses khlorinasifiltrasi dan proses oksidasi kalium permanganatfiltrasi dengan mangan zeolit (manganese greensand) (Said, N.I. 2008).

Dari hasil analisa kualitas air sumur di Ponpes Ummul Quro menunjukkan bahwa nilai konsentrasi mangan cukup tinggi, maka proses yang digunakan untuk menurunkan mangan adalah gabungan proses aerasi dan pembubuhan kalium permanganat serta filtrasi atau penyaringan.

Proses aerasi adalah proses dimana udara ditambahkan kedalam air baku agar zat mangan yang ada di dalam air baku bereaksi dengan oksigen membentuk senyawa sebagai berikut :

$$
2 \mathrm{Mn}^{2+}+\mathrm{O}_{2}+2 \mathrm{H}_{2} \mathrm{O} \rightarrow 2 \mathrm{MnO}_{2}+4 \mathrm{H}^{+}
$$

Kemudian berikutnya adalah dengan proses oksidasi dengan membubuhkan atau menginjeksi dengan oksidator kalium permanganat kedalam air dengan persamaan reaksi sebagai berikut :

$2 \mathrm{Mn}^{2+}+2 \mathrm{KMnO}_{4}+2 \mathrm{H}_{2} \mathrm{O} \rightarrow 5 \mathrm{MnO}_{2}+4 \mathrm{~K}^{+}+4 \mathrm{H}^{+}$ 
Larutan kalium permanganat secara kontinyu diinjeksikan ke dalam air baku sebelum proses filtrasi. Proses injeksi larutan kalium permanganat tersebut menggunakan pompa dosing yang dapat diatur laju pembubuhannya.

Setelah dilakukan aerasi dan injeksi kalium permanganat, selanjutnya dilakukan proses filtrasi yaitu memompa air baku tersebut ke tabung filter dengan media filter berisi mangan zeolit (manganese greensand). Mangan zeolit adalah mineral yang dapat menukar elektron sehingga dapat mengoksidasi mangan yang larut di dalam air menjadi bentuk yang tidak larut sehingga dapat dipisahkan dengan penyaringan. Persamaan reaksinya sebagai berikut :

$$
\begin{aligned}
\mathrm{K}_{2} \mathrm{Z} \cdot \mathrm{MnO} \cdot \mathrm{Mn}_{2} \mathrm{O}_{7} & +2 \mathrm{Mn}\left(\mathrm{HCO}_{3}\right)_{2} \rightarrow \mathrm{K}_{2} \mathrm{Z}+5 \mathrm{MnO}_{2} \\
& +4 \mathrm{CO}_{2}+2 \mathrm{H}_{2} \mathrm{O}
\end{aligned}
$$

Filtrat yang terjadi mengandung mangandioksida yang tak larut dalam air dan dapat dipisahkan dengan penyaringan dan pengendapan.

Selama proses berlangsung kemampuan reaksinya makin lama makin berkurang dan akhirnya menjadi jenuh. Untuk regenerasinya dapat dilakukan dengan menambahkan larutan kalium permanganat kedalam mangan zeolite yang telah jenuh tersebut sehingga akan terbentuk lagi mangan zeolite $\left(\mathrm{K}_{2} \mathrm{Z} \cdot \mathrm{MnO} \cdot \mathrm{Mn}_{2} \mathrm{O}_{7}\right)$ (Said, N.I. 2005).

\subsection{Unit Pengolahan Air Siap Minum (Arsinum)}

Kapasitas unit pengolahan air siap minum (Arsinum) dapat menghasilkan air minum sampai 5.000 liter per hari yang dilengkapi dengan tangki air produk 1.000 liter dan lemari pengisian dan pencucian/ pembilasan galon (Gambar 1). Unit ini juga dilengkapi dengan sistem outlet dispenser yang menghasilkan air minum panas dan dingin Gambar 2).

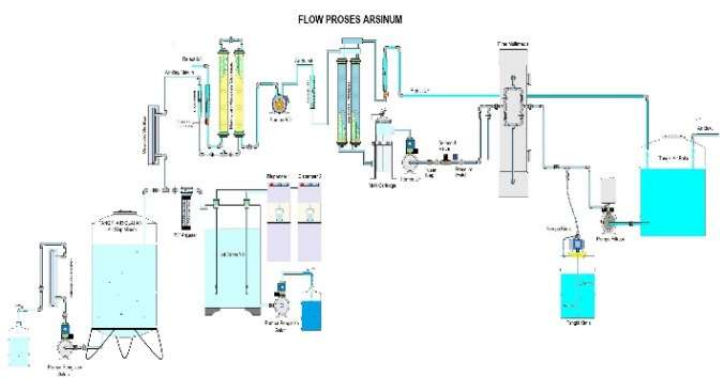

Gambar 1. Diagram Pengolahan Air Siap Minum

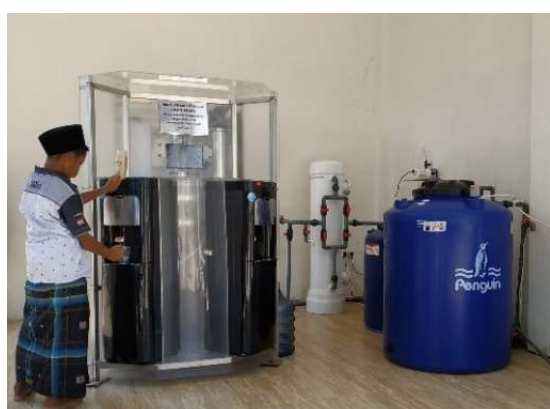

Gambar 2. Foto Unit Pengolahan Air Siap Minum

\subsection{Proses Pengolahan}

Proses pengolahan unit Arsinum terbagi menjadi 3 tahapan yaitu :
a. Pengolahan awal / Pretreatment
b. Pengolahan lanjut / Advance Treatment
c. Pengolahan akhir / Post Treatment

\subsubsection{Pengolahan awal / Pretreatment}

Lebih dahulu air yang akan diolah atau disebut sebagai air baku dipompa ditampung pada tangki air baku, proses penampungan ini dengan mengalirkan air dari bagian atas tangki sehingga memungkinkan terjadinya proses aerasi yang akan mengoksidasi sebagian kandungan mangan $(\mathrm{Mn})$ yang terlarut pada air baku sehingga terbentuk oksidan kehitaman pada dinding tangki yang menandakan proses aerasi berlangsung dengan baik (Gambar 3).

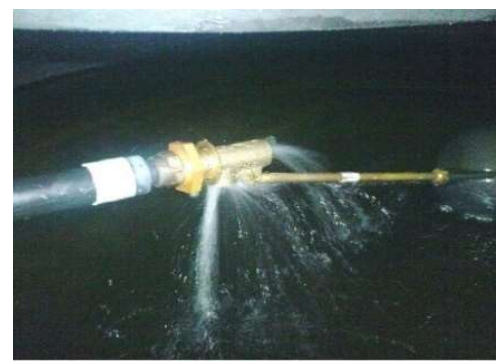

Gambar 3. Proses Aerasi dalam Tangki Air Baku

Air baku kemudian di alirkan ke filter multimedia menggunakan pompa. Proses selanjutnya air baku akan melewati filter multimedia dengan susunan media terdiri dari kerikil, pasir silika, mangan zeolit dan karbon aktif (Gambar 4). Filter berfungsi untuk menghilangkan pengotornya yang ukurannya setara atau melebihi dari 100 mikron yang tertahan pada media saring pasir silika, lalu air baku akan melewati lapisan media Manganese Zeolit untuk diserap sisa mangannya yang terlarut pada air baku, kemudian melewati lapisan karbon aktif untuk dihilangkan bau dan warna yang terdapat pada air baku. Sebagian besar proses penurunan mangan terjadi pada 
tahapan pengolahan awal ini. Filter yang digunakan mempunyai tinggi $120 \mathrm{~cm}$, berdiameter 12 inchi dengan bahan Polivinil Klorida (PVC) dan dilengkapi dengan kerankeran yang berfungsi sebagai pengatur arah aliran untuk penyaringan dan untuk pencucian balik (bachwash) serta susunan medianya seperti ditunjukkan pada gambar 4 .

Pada saat yang bersamaan diinjeksikan larutan Kalium Permanganat sebanyak 30 ppm kedalam pipa saluran air baku sebelum menuju filter multimedia (Gambar 5). Tujuan injeksi larutan Kalium Permanganat dengan bantuan dosing pump (Gambar 6) ini sebagai disinfektan yang akan menurunkan kandungan mikroorganisme pada air baku. Larutan ini juga difungsikan sebagai oksidator mangan $(\mathrm{Mn})$ yang masih tersisa pada air baku. Reaksi oksidasi tersebut menghasilkan senyawa mangan dioksida yang berupa gumpalan sangat halus (micro flock) yang tak larut dalam air, sehinggga dapat tersaring pada filter multimedia. Berdasarkan reaksi oksidasi tersebut, untuk mengoksidasi setiap setiap 1,0 mg/liter mangan diperlukan oksigen sebanyak 0,29 mg/liter (Said, NI. 2008).

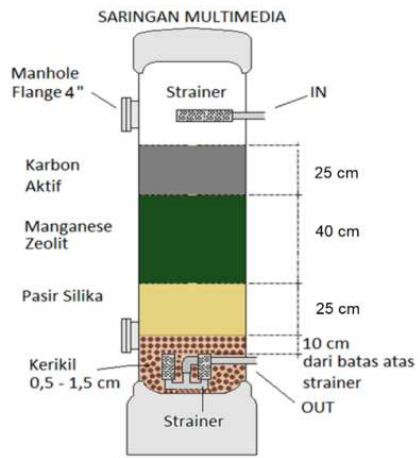

Gambar 4. Susunan Media Saring Pretreatment

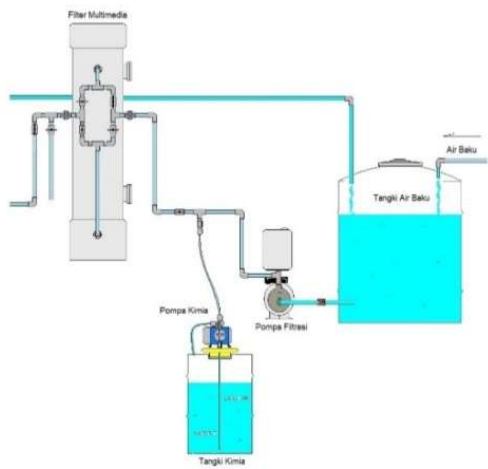

Gambar 5. Diagram Pengolahan Pretreatment

Untuk itu diperlukan pemantauan berkala terhadap kualitas air olahan, apabila terdapat indikasi kenaikan nilai mangan maka segera dipertimbangkan untuk melakukan regenerasi atau mengganti media Manganese Zeolit.

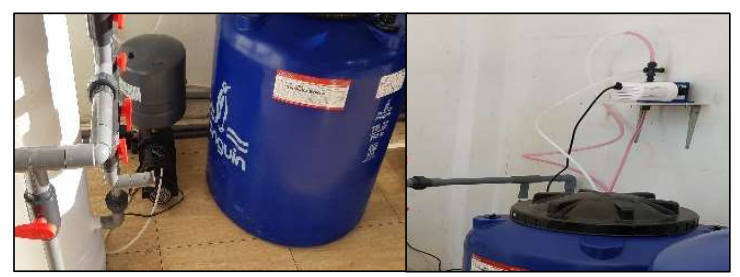

Gambar 6. Pompa Air Baku, Tangki kimia dan Dosing Pump

\subsubsection{Pengolahan lanjut / Advance Treatment}

Air bersih hasil proses pengolahan awal selanjutnya dialirkan menuju proses selanjutnya yaitu proses penyaringan dengan membran Ultrafiltrasi dan Reverse Osmosis (RO) yang ditunjukkan pada Gambar 6 dan 7. Dalam fase ini air bersih akan melewati 3 (tiga) tahapan penyaringan, pertama air akan melalui saringan skala mikro yaitu jenis multi cartridge dimana besaran ukuran penyaringan ini adalah 10 mikron, terdiri dari lima 5 (lima) media isian dengan dimensi media 2" x 20" yang terbuat dari bahan sintetis selulosa berbentuk silinder dengan lubang keluaran ditengahnya. Setelah melewati saringan mikro air baku menuju saringan membran ultrafiltrasi dimana ukuran penyaringanya sampai dengan 0,001 mikron, teknis penyaringan membran yang dimaksud adalah pemisahan larutan atau fluida dari komponen makromolekul secara langsung tanpa menggunakan panas (Khofia, H.N, dkk. 2012). Komponen-komponen akan terpisah berdasarkan ukuran dan bentuknya, dengan bantuan tekanan imitasi dari pompa dan selaput semi-permeable. Hasil pemisahan berupa rejection (bagian dari material yang tidak bisa melewati membran) dan permeate (bagian dari larutan yang mampu melewati membran) (Widyasmara dan Dewi, 2013).

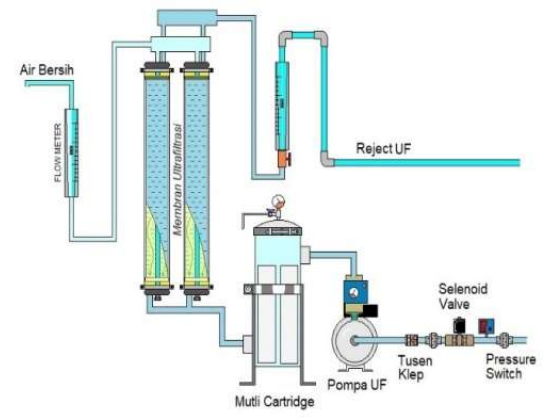

Gambar 7. Diagram Pengolahan Lanjut Penyaringan Ultrafiltrasi

Terdapat 2 (dua) hasil keluaran dari penyaringan Ultrafiltrasi yaitu air buangan (reject) dan air hasil olahan (product), air reject dialirkan kembali ke tangki air baku untuk diolah kembali 
sebagai air baku. Sedangkan hasil olahannya dialirkan ke penyaringan menggunakan membran $R O$.

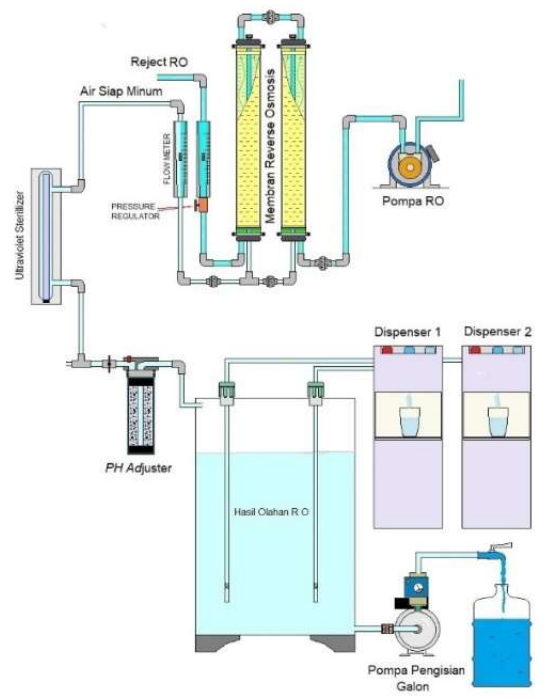

Gambar 8. Diagram Pengolahan Lanjut Penyaringan RO

Pada tahap ini air olahan dari hasil penyaringan ultrafiltrasi ditingkatkan kualitas menjadi air siap minum. Sama dengan proses ultrafiltrasi, proses RO juga mempunyai 2 (dua) hasil keluaran yaitu air buangan (reject) dan air hasil olahan (product). Air buangan/reject dapat dimanfaatkan sebagai air bersih (mencuci, bilas dan siram) dan tidak untuk dikonsumsi sebagai ari minum. Besaran ukuran penyaringan ini sampai dengan 0,0001 mikron, dimana hasil olahan sudah memenuhi standar baku mutu air minum. Air olahan tersebut ditampung pada tangki air olahan untuk dikonsumsi sebagai air minum. Sebelum masuk ke penampungan air siap minum melewati Ultraviolet Sterillizer dan PH Adjuster.

Unit penyaringan Ultrafiltrasi dan RO ini tergabung dalam satu rangka yang terintegrasi, dan terangkai menjadi satu unit utuh sehingga memudahkan waktu instalasi dan mobilisasi.

\subsubsection{Pengolahan akhir / Post Treatment}

Setelah air olahan melalui Ultraviolet dan $\mathrm{PH}$ Adjuster, air dicabang menjadi 2 aliran satu menuju tangki penampung air baku yang terletak didalam unit pengolahan lanjut, sedangkan satunya dialirkan menuju tangki penampung dengan volume 1.000 liter yang terletak diluar unit pengolahan lanjut. Unit pengolahan akhir ini terdiri dari :

1. Tangki penampung 1.000 liter,

2. Lemari pengisisan galon,

3. Pompa pengisisan galon,

4. Ultraviolet sterilizer.
Unit ini memang didisain khusus untuk dapat melakukan pengisian air olahan kedalam galon secara masiv dan cepat untuk dapat didistrbusikan ke masyarakat. Untuk ini juga dilengkapi mekanisme pencucian galon dengan cara disemprotkan air siap minum dengan tekanan kedalam botol dengan posisi terbalik sehingga dapat membilas permukaan bagian dalam botol menjadi bersih.

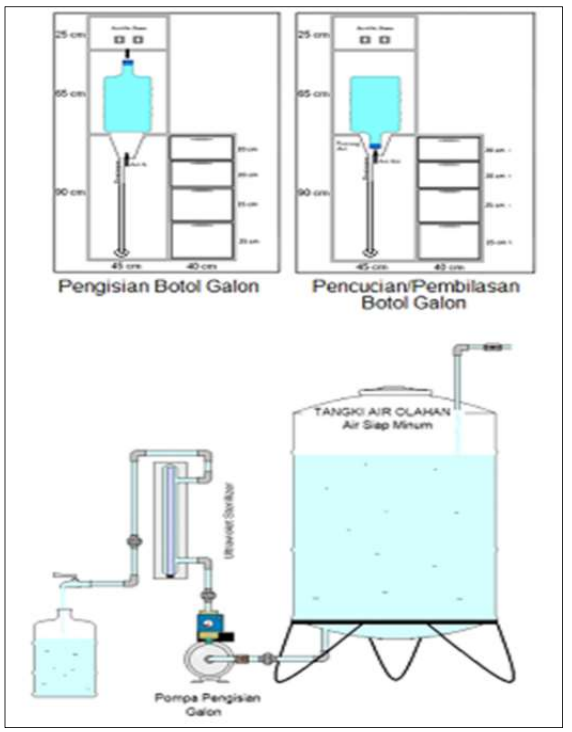

Gambar 9. Lemari Pengisian/pembilasan Galon dan tangki Air Olahan Arsinum

\section{Hasil Pengolahan}

Hasil uji coba pilot plan untuk menghilangkan kadar mangan (Mn) tinggi dalam air dengan kombinasi proses oksidasi dengan udara atau aerasi, pembubuhan kalium permanganat dan dilanjutkan dengan proses penyaringan/filtrasi dengan mangan zeolit, serta ditambah dengan proses penyaringan ultrafiltrasi dan RO ditunjukkan pada Tabel 2. Tabel 2 menunjukkan bahwa terjadi penurunan kadar mangan (Mn) dari 5,77 mg/liter menjadi 0,26 $\mathrm{mg} / \mathrm{liter}$, kesadahan meskipun masih dibawah baku mutu diturunkan dari $160,0 \mathrm{mg} / \mathrm{liter}$ menjadi $35,0 \mathrm{mg} / \mathrm{liter}$.

Tabel 2. Hasil Analisa Kualitas Air Baku dan Air Olahan

\begin{tabular}{c|l|c|c|c|c}
\hline No & PARAMETER & SATUAN & $\begin{array}{c}\text { Baku } \\
\text { Mutu }\end{array}$ & $\begin{array}{c}\text { Hasil } \\
\text { Air } \\
\text { Baku }\end{array}$ & $\begin{array}{c}\text { Hasil } \\
\text { Air } \\
\text { Olahan }\end{array}$ \\
\hline 1 & $\mathrm{pH}$ & - & $6-9$ & 6,87 & 6,71 \\
\hline 2 & Kekeruhan & $\mathrm{NTU}$ & 5 & 1,07 & 0,58 \\
\hline 3 & $\begin{array}{l}\text { Jumlah zat } \\
\text { padat terlarut } \\
\text { (TDS) }\end{array}$ & $\mathrm{mg} / \mathrm{l}$ & 500 & 222 & 30,0 \\
\hline 4 & Temperatur & ${ }^{\circ} \mathrm{C}$ & $\begin{array}{c}\text { Air } \\
\text { Normal }\end{array}$ & 26 & 26,0 \\
\hline 5 & Klorida & $\mathrm{mg} / \mathrm{l}$ & 250 & 17,30 & 3,93 \\
\hline
\end{tabular}




\begin{tabular}{c|l|c|c|c|c}
\hline No & PARAMETER & SATUAN & $\begin{array}{c}\text { Baku } \\
\text { Mutu }\end{array}$ & $\begin{array}{c}\text { Hasil } \\
\text { Air } \\
\text { Baku }\end{array}$ & $\begin{array}{c}\text { Hasil } \\
\text { Air } \\
\text { Olahan }\end{array}$ \\
\hline 6 & $\begin{array}{l}\text { Kesadahan } \\
\text { jumlah } \\
\left(\text { CaCO }_{3}\right)\end{array}$ & $\mathrm{mg} / \mathrm{l}$ & 500 & 160,00 & 35,00 \\
\hline 7 & Nitrit & $\mathrm{mg} / \mathrm{l}$ & 3 & $<0,1$ & $<0,01$ \\
\hline 8 & Nitrat & $\mathrm{mg} / \mathrm{l}$ & 50 & 1,55 & 0,22 \\
\hline 9 & Amonia & $\mathrm{mg} / \mathrm{l}$ & 1,5 & 0,02 & 0,022 \\
\hline 10 & Sulfat & $\mathrm{mg} / \mathrm{l}$ & 250 & 1,40 & 1,16 \\
\hline 11 & Flourida & $\mathrm{mg} / \mathrm{l}$ & 1,5 & 1,19 & 0,03 \\
\hline 12 & $\begin{array}{l}\text { Besi (Fe) } \\
\text { Terlarut }\end{array}$ & $\mathrm{mg} / \mathrm{l}$ & 0,3 & $<0,02$ & $<0,02$ \\
\hline 13 & $\begin{array}{l}\text { Kadmium } \\
\text { (Cd) Terlarut }\end{array}$ & $\mathrm{mg} / \mathrm{l}$ & 0,003 & $<0,002$ & $<0,002$ \\
\hline 14 & Mangan (Mn) & $\mathrm{mg} / \mathrm{l}$ & 0,4 & 5,77 & 0,26 \\
\hline 15 & $\begin{array}{l}\text { Seng (Zn) } \\
\text { Terlarut }\end{array}$ & $\mathrm{mg} / \mathrm{l}$ & 3 & $<0,008$ & $<0,008$ \\
\hline 16 & $\begin{array}{l}\text { Krom (Cr) } \\
\text { Terlarut }\end{array}$ & $\mathrm{mg} / \mathrm{l}$ & 0,05 & $<0,02$ & $<0,02$ \\
\hline 17 & $\begin{array}{l}\text { Tembaga } \\
\text { (Cu) Terlarut }\end{array}$ & $\mathrm{mg} / \mathrm{l}$ & 2 & $<0,02$ & $<0,02$ \\
\hline 18 & $\begin{array}{l}\text { Nikel (Ni) } \\
\text { Terlarut }\end{array}$ & $\mathrm{mg} / \mathrm{l}$ & 0,07 & $<0,01$ & $<0,01$ \\
\hline 19 & Total Coliform & $\mathrm{mpn} / 100$ & 50 & 23 & 0,00 \\
\hline 20 & E Coli & $\mathrm{mL}$ & 0 & - & - \\
\hline & & & & & $<$ \\
\hline
\end{tabular}

\section{KESIMPULAN}

Unit pengolahan air siap minum (Arsinum) yang telah dibangun di Pondok Pesantren Ummul Quro di Kabupaten Trenggalek dapat menurunkan kadar mangan (Mn) tinggi dalam air secara signifikan. Hasil analisa air olahan produk Arsinum menunjukkan bahwa kadar mangan memenuhi persyaratan kualitas untuk air minum menurut Keputusan Menteri Kesehatan Republik Indonesia Nomor 492/MENKES/PER/IV/ 2010.

Kombinasi proses aerasi, injeksi larutan kalium permanganat dan filtrasi dengan media pasir silika, mangan zeolit dan karbon aktif dapat menurunkan kadar mangan cukup efektif.

\section{PERSANTUNAN}

Ucapan terima kasih disampaikan kepada Direktur Pusat Teknologi Lingkungan, TPSABPPT yang telah mendukung dan mendanai kegiatan ini. Tak lupa terimakasih kepada Pimpinan Yayasan Nurul Fikri dan Pimpinan beserta jajaran staf Pondok Pesantren Tahfidzul Qur'an Ummul Quro, Kabupaten Trenggalek yang telah membantu sepenuhnya dalam pelaksanaan kegiatan ini.

\section{DAFTAR PUSTAKA}

1. Ahyar, Agus (2017). Peningkatan Kapasitas Pelayanan Penyelenggara Sistem Penyediaan Air Minum (SPAM). Disampaikan dalam Musyawarah Antar Perusahaan Air Minum Tingkat Nasional (Mapamnas) XIII Perpamsi, Jakarta, 06 Desember 2017.
2. Aisyahwalsiah, A, dkk. (2010). Pencemaran Tanah dan Air Tanah Pengaruh Mangan Dalam Air. Program Studi Teknik Lingkungan, Fakultas Teknik, Universitas Lambung Mangkurat.

3. Anonimous 1, (2007) Buku Panduan Pengembangan Air Minum, RPIJM, Ditjen Cipta Karya, Dep. PU.

4. Anonimous 2, (2014). Potensi Bahan Tambang dan Mineral dirinci Menurut Kecamatan di Kabupaten Trenggalek. Dinas Koperasi, Industri, Perdagangan, Pertambangan Dan Energi, Kabupaten Trenggalek.

5. Anonimous 3. 2010. Keputusan Menteri Kesehatan Republik Indonesia Nomor 492/MENKES/PER/IV/2010 Tentang Pesyaratan Kualitas Air Minum.

6. Ashar, T. (2007). Analisis Risiko Asupan Oral Pajanan Mangan dalam Air Terhadap Kesehatan Masyarakat. Jurnal Kesehatan Masyarakat Nasional Vol. 2, No. 3, 106-111, Desember 2007.

7. Febrina, L. \& Ayuna, A. 2015. Studi Penurunan Kadar Besi ( $\mathrm{Fe}$ ) dan Mangan (Mn) dalam Air Tanah Menggunakan Saringan Keramik. Jurnal Teknologi Vo. 7, No. 1, 35-44. Universitas Muhammadiyah Jakarta.

8. Khofia, H.N, dkk. 2012. Uji Sterilitas Dengan Tekhnik Penyaringan Membran. Tugas Mata Kuliah Teknologi Sediaan Farmasi, Jurusan Farmasi, Universitas Soedirman. Available from:https://tsffarmasiunsoed2012.wordpres s.com/2012/05/23/uji-sterilitas-dengantekhnik-penyaringan-membran/

9. Said, N.I. (2005). Metoda Penghilangan Zat Besi dan Mangan Dalam Penyediaan Air Minum Domestik. Jurnal Air Indonesia, Vol. 1, No. 3. 239-250. BPPT, Jakarta.

10. Said, N.I. (2008). Buku Teknologi Pengelolaan Air Minum, Teori dan Pengalaman Praktis. Penerbit Pusat Teknologi Lingkungan, TPSA, BPPT.

11. Setiyono, A. (2014). Studi Kadar Mangan (Mn) Pada Air Sumur Gali Di Desa Karangnunggal Kecamatan Karang-nunggal, Kabupaten Tasikmalaya. Jurnal Kesehatan Komunitas Indonesia. Vol. 10, No. 1, 973981. Maret 2014.

12. Widyasmara M, dan Dewi, CK. 2013 Potensi Membran Mikrofilter dan Ultrafiltrasi untuk pengolahan Limbah Cair Berminyak. Jurnal Teknologi Kimia dan Industri, Vol. 2, No. 2, 295-307, Jurusan Teknik Kimia, Fakultas Teknik Universitas Dipenogoro.

13. Yulianti, D (2013). Buku Potensi Mangan Di Gunung Kuncung, Kecamatan Pogalan, Kabupaten Trenggalek. Penerbit STEM Akamigas. 